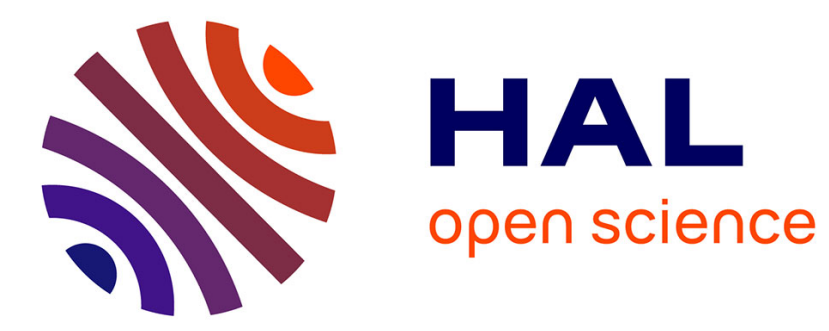

\title{
On the Semiotic Parameters of Narrative: A Critique of Story and Discourse
}

\author{
John Pier
}

\section{To cite this version:}

John Pier. On the Semiotic Parameters of Narrative: A Critique of Story and Discourse. Tom Kindt; Hans-Harald Müller. What is Narratology? Questions and Answers Regarding the Status of a Theory, Walter de Gruyter, pp.73-98, 2003, Narratologia. hal-01229464

\section{HAL Id: hal-01229464 https://hal.science/hal-01229464}

Submitted on 30 Nov 2015

HAL is a multi-disciplinary open access archive for the deposit and dissemination of scientific research documents, whether they are published or not. The documents may come from teaching and research institutions in France or abroad, or from public or private research centers.
L'archive ouverte pluridisciplinaire HAL, est destinée au dépôt et à la diffusion de documents scientifiques de niveau recherche, publiés ou non, émanant des établissements d'enseignement et de recherche français ou étrangers, des laboratoires publics ou privés. 
JOHN PIER

(Paris, Tours)

\section{On the Semiotic Parameters of Narrative: A Critique of Story and Discourse}

One of the major achievements of narratology has been to delineate categories for the analysis of stories and to organize them in accordance with various theories in such a way that they both apply to individual works and fit into broader classifications. The process has been enriched by the going-and-coming between the analysis of narratives and theoretical reflection, the one nourishing the other, but it is also a process that bears the marks of historical evolution: the categories of analysis, and their terminology, interact with those of similar or competing theories, producing new paradigms or resulting in revisions of those that already exist. Such development is, of course, the motor of innovation, but it sometimes leads to the congealing of tentative syntheses into standardized procedures and methodologies which, however influential and productive they might be, call for reexamination, even, or sometimes especially, with several years' hindsight ${ }^{1}$.

This is the case, I find, with the story/discourse theory of narrative. In what can be regarded as a canonical position of classical narratology, Seymour Chatman stated in 1978 that "each narrative has two parts: a story (histoire), the content or chain of events (actions, happenings), plus what may be called the existents (characters, items of setting); and a discourse (discours), that is, the expression, the means by which the content

I wish to thank Gerald Prince and Malte Stein for their thoughtful reading of this paper and their helpful comments. 
is communicated. In simple terms, the story is the what in a narrative that is depicted, discourse the how"'. Few would deny that narratives - or indeed any form of discourse-have their "what" and their "how," whatever the terminological and conceptual mazes lurking beneath the surface of these apparently straightforward terms. In a way, Chatman's definition of the story/discourse theory of narrative comes as a summary of more than ten years of narratological research at a time when the waning of structuralist linguistics, the so-called "pilot science" of narrative theory, had already sparked off a "crisis," resulting in a significant shift in the parameters of narratological research.

As is nearly always the case with research, the story/discourse theory has been paralleled by more or less alternative approaches, one in particular being the so-called ternary model: histoire (story), récit (narrative), narration (narrating) ${ }^{3}$; story, text, narration ${ }^{4}$; fabula, story, text ${ }^{5,6}$. From a somewhat different perspective, David Herman has observed that postclassical narratology - not to be confused with poststructuralism - comprises three overlapping areas of investigation: narrative grammar (following Propp and his successors); narrative poetics (description and classification of the relations between the narrated and the narrative); rhetoric ("the study of the forms of narrative vis-à-vis the audiences of narrative") ${ }^{7}$. In an earlier study, Universal Grammar and Narrative Form ${ }^{8}$, Herman had taken a cue from Todorov's Grammaire du Décaméron ${ }^{9}$ by

2

3

4

5

6

7

Herman (1999: 7). According to Herman, the transition from classical to post-classical narratology can be dated to an article by David Lodge (1980) which takes stock of three models for narrative that developed during the 1970s: "narratology and narrative grammar"; "poetics of fiction"; "rhetorical analysis." Note can also be taken of an article by Robert Scholes (1980) suggesting the merits for narrative theory of Peirce's "trirelative" notion of semiosis (comparable to Frege's, Ogden/Richard's and Carnap's Herman (1995). 
caméron ${ }^{9}$ by adopting the three components of Modistic grammar in order to examine, with reference to Charles Morris (among others), the syntactics, semantics, and pragmatics of narrative. This very brief survey suggests that narratology contained early on elements of a semiotic nature which, while not undermining the idea that narratives in some way comprise content and expression, call into question the story/discourse model or, at the very least, require a disambiguating of the terms story and discourse. Indeed, these matters could well form a crucial portion in a detailed study devoted to the genealogy of narratological concepts. The aim of the present paper, however, is to disentangle the terms and concepts that have contributed to this model. In doing so, we will see that, in order to have a better grasp of the "what" and the "how" of narrative, it is useful, if not necessary, to examine some of the principal ways in which they are subdivided and conceptualized.

The meanings attributed to story and discourse have been conveniently identified in Gerald Prince's Dictionary of Narratology:

Story:

1) the content plane of narrative;

2) the fabula;

3) a narrative of events with an emphasis on chronology;

4) a causal sequence of events;

5) a linguistic subsystem in which neither sender nor receiver are implied.

Discourse:

1) the expression plane;

2) a linguistic subsystem implying a sender and a receiver ${ }^{10}$.

As a starter, it is, of course, useful to single out these meanings, if only to point toward the conceptual disparities between the two terms, as can be seen, for example, from the absence in discourse of any counterpart under story to item 2 (fabula), item 3 (a narrative of events with an emphasis on chronology) and item 4 (a causal sequence of events). To offset this imbalance and get a somewhat more complete picture, we need to turn to another entry:

9 Todorov (1969).

10 Prince (1987: 21, 91). 
Plot:

1) the main incidents of a narrative (as opposed to character and theme);

2) the arrangement of incidents (muthos, sjuzhet);

3) the global dynamic organization of narrative constituents responsible for the thematic interest of a narrative;

4) plot as defined by Forster ${ }^{11}$.

In this entry, item 2 (arrangement of incidents) and item 4 (Forster's plot) have their counterparts in story but do not form part of discourse. In practice, then, it seems that the passage of the terms "story" and "discourse" into current narratological usage marks an uneasy and somewhat reductive synthesis of concepts that are not wholly assimilable into one another and that, in some cases, pertain to divergent approaches to narrative theory and analysis. When cast against the backdrop of Prince's lexicological treatment of the terms, it can be seen that a story/discourse model of narrative such as Chatman's is a structuralist theory that seeks to incorporate prestructuralist concepts, but also certain linguistic and semiotic categories.

\section{Pre-structuralist}

In its best-known version, outlined by Boris Tomashevsky, the $f a$ bula/sjuzhet principle distinguishes between "the aggregate of mutually related events reported in the work" ("the action itself") and "the same events, but [...] arranged and connected according to the orderly sequence in which they were presented in the work" ("how the reader learns of the action"). The fabula is composed of irreducible thematic elements, or motifs, each containing a predicate, some of these motifs being bound together "in their logical, causal-chronological order" such that they cannot be eliminated without upsetting the whole of the narrative, others being free ${ }^{12}$.

Wolf Schmid has observed that the core meaning of fabula is "material for formation of the sjuzhet" ("Material der Sujetformung") and that of sjuzhet "formation of the fabula material" ("Formung des Fabelmateri-

\footnotetext{
11 Prince (1987: 71-72).

12 Tomashevsky (1965: 66-68).
} 
als"), resulting in an inherent semantic and esthetic reductionism ${ }^{13}$. It has also been shown that, among Slavic scholars, the Formalist dichotomy has been dealt with in ways that have little to do with the story/discourse model of classical narratology ${ }^{14}$. A case in point is Lubomír Dolezel's "stratificational" model which subdivides fabula into motifemes (logical structures in propositional form representing classes of texts independent of any textual manifestation) and motifs (organization of the content of individual narratives with an extensional structure), while sjuzhet is a "texture" (the wording of narratives as they appear in texts) ${ }^{15}$.

Story, says E. M. Forster, is "a narrative of events arranged in their time-sequence" ("The king died and then the queen died"); "a plot is also a narrative of events, the emphasis falling on causality" ("The king died, and then the queen died of grief") ${ }^{16}$. For the unwary, this well-known pair might appear to be synonymous with fabula/sjuzhet, the risk of confusion in no way being alleviated by the lack of satisfactory English equivalents for the Russian words, which are commonly rendered "story" and "plot" (cf. Reis and Lemon's translation of Tomashevsky's article; Erlich ${ }^{17}$ gives "fable" and "plot").

Meir Sternberg ${ }^{18}$ is one of the few to maintain that the two sets of concepts have different modes of existence and that they are neither interchangeable nor mutually exclusive, but complementary. He points out that sjuzhet is the actual text as given, a largely antichronological rearrangement of motifs to be reconstituted through a process of abstraction in their "objective" order as they appear in the fabula. Neither story nor plot, however, is primarily concerned with motifs or their (re-)ordering, but with the nature of linkages: temporal or causal. Both story and fabula are thus abstractive, reconstitutive and indispensable to narrative. However, plot, unlike sjuzhet, is abstractive and can be (and in actual texts sometimes is) dispensed with; sjuzhet, which is indispensable, can include a variety of linkages - temporal, causal, visual or other. For Sternberg, sjuzhet is thus akin to the Aristotelian muthos, that is, the "arrangement or structure of incidents" (sunthesin tôn pragmatôn [Poetics 1450a]). As Er-

\footnotetext{
13 Schmid (1982: 83, 87).

14 Volek (1977: 155ff.).

15 Dolezel (1972); cf. (1998: 33-36).

16 Forster (1962: 93).

17 Erlich (1965: 240-42).

18 Sternberg (1978: 8-14).
} 
lich (1965: 242) has noted, however, sjuzhet is characterized mainly by its temporal displacements of fabula and is thus a somewhat looser concept than muthos. This being the case, it is understandable that Volek (1977: 147) takes nearly the opposite view from Sternberg, observing that Forster's plot, in conjoining "why" with "and then," comes closer to the systematic character of the Formalist fabula than it does to sjuzhet: for him, it is plot and fabula (but not sjuzhet) that can be likened to Aristotle's muthos.

Combining the two pairs of terms, Sternberg goes on to propose an eight-term typology based on their intersection ${ }^{19}$. The important point for us, however, is that, in view of the technical senses of the four terms, any conflation of the two pairs of binary terms into a single binary pair tends to mask significant conceptual differences between them.

\section{Structuralist}

The story/discourse model incorporates structuralist principles through the adoption of Claude Bremond's raconté/racontant and Tzvetan Todorov's histoire/discours.

With reference to Propp's morphological model, Bremond focuses on "an autonomous layer of meaning, provided with a structure that can be isolated from the whole of the message: the narrative." The narrative (récit), without which there cannot be a "narrative message," tells (raconte) a story (histoire) that possesses a structure "independent of the techniques by which it is taken over." It is further specified that "[t]he raconté has its own signifiers, its racontants: these are not words, images or gestures, but the events, situations and behaviors signified by these words, these images, these gestures" 20 .

Bremond's racontélracontant is an obvious evocation of Saussure's signifié/signifiant, but one that calls for qualification. Different media

${ }^{19}$ For example, picaresque novels form a "story-type sujet" whereas the reconstituted

${ }_{20}$ pattern of stream-of-consciousness novels constitute a "story-like fabula."

Bremond (1973: 11-12): "une couche de signification autonome, dotée d'une structure qui peut être isolée de l'ensemble du message: le récit [...] [La structure de l'histoire] est indépendante des techniques qui la prennent en charge [...] Le raconté a ses signifiants propres, ses racontants: ceux-ci ne sont pas des mots, des images ou des gestes, mais les événements, les situations et les conduites signifiés par ces mots, ces images, ces gestes." 
(words, images, gestures) can convey the same story. Story, however, is not assimilable to the linguistic signified, since the events, situations and behaviors of the story constitute the properly narrative signifiers of the récit, i.e. racontants; nor is the raconté a signified in the linguistic sense, but the properly narrative signified of the récit, i.e. a structure of functions. Moreover, in order for narrative as an isolated layer of meaning to become communicable, it must be taken over by techniques which, in turn, employ a given system of signs ${ }^{21}$. In effect, then, Bremond's model is a four-level "interlocking" system which subdivides Propp's fabula into racontélracontant, while the techniques through which this "autonomous structure" is conveyed (cf. sjuzhet) employ the signifieds and signifiers of particular media: hence, a sign system acts as the signifier of narrative techniques (the "signifieds" of that of that system) which, in turn, overlap with the racontants that serve as the signifiers of the racontés. Indeed, Bremond $^{22}$ does insist on the division between "the laws that govern the narrated universe" and "analysis of the techniques of narration," but to ignore the subdivision of the two sectors can result in misleadingly positing raconté/racontant as the transposition of the linguistic signifié/signifiant onto narrative categories.

In his story/discourse model, Chatman has not overlooked this dual distinction, but the terminology employed largely neutralizes it. Noting that raconté (translated as "that which is narrated") and racontant ("storyelements") incorporate the same distinctions as fabula and sjuzhet ${ }^{23}$, he goes on to state that "[t]he signifiés or signifieds of narrative are exactly three - event, character, and detail of setting; the signifiants or signifiers are those elements in the narrative statement (whatever the medium) that can stand for one of these three $[\ldots]^{3,24}$. Here, four levels are delineated

21 " $[\mathrm{T}]$ he narrative, although existing as an autonomous signifying structure, is communicable only on condition that it is relayed by a narrative technique, this technique using the system of signs which is appropriate to it. In other words, the signifying elements of the narrative (the racontants) become the signifieds of the technique by which they are taken over." ("[L]e récit, bien qu'existant comme structure signifiante autonome, n'est communicable que sous condition d'être relayé par une technique de récit, celleci utilisant le système de signes qui lui est propre. C'est dire que les éléments signifiants du récit (les racontants) deviennent les signifiés de la technique qui les prend en charge" (ibid.: 46).

Bremond (1966: 60).

23 Chatman (1978: 20).

24 Ibid.: 25 . 
(signifieds, signifiers, narrative statement, medium), but this is done in such a way that in place of racontés and racontants, we find signifiés in a sense close to Bremond's racontants (events, situations, behaviors) and signifiants in a sense that is barely distinguishable from Bremond's "techniques". Although in principle, story and discourse have each been subdivided, the result of the slight shifts in terminology and their accompanying concepts is that story and discourse, along with racontélracontant and fabula/sjuzhet, are effectively assimilated into signified and signifier.

The immediate terminological predecessor of the story/discourse model is histoire and discours, a pair that in fact covers two sets of categories.

Originally, histoire/discours was proposed by Émile Benveniste to distinguish, through the use of pronouns, deictics and verbal systems, between two modes of enunciation (énonciation) in the French language: briefly stated, histoire consists in third-person enunciations that exclude "autobiographical" forms while discours, in the first and second persons, includes "all enunciations which assume a speaker and a hearer, the first intending to influence the other in some way"25.

Responses to Benveniste's work have been various, and its application to literature has been prolific, although not unproblematic, particularly as regards the relative positions of histoire and discours in actual texts. Harald Weinrich ${ }^{26}$, for example, in his carefully-elaborated development of Benveniste's thesis, integrated it into text linguistics, but with the conclusion that, due to the particularities of the verbal system of the Romance languages, it does not readily extend to other languages. In a way not to be confused with the story/discourse theory of narrative, Ann Banfield ${ }^{27}$, adopted Benveniste's distinction within the context of narrative style in order to study represented speech and thought (with particular reference to free indirect speech), discursive forms which, unlike direct speech, are noncommunicative; she also renames histoire "narration," maintaining that Benveniste's histoire/discours is complementary, but not equivalent,

\footnotetext{
25 Benveniste (1966: 242): "toute énonciation supposant un locuteur et un auditeur, et chez le premier l'intention d'influencer l'autre en quelque manière."

26 Weinrich (1971).

27 Banfield (1982: 141ff. and passim).
} 
to Käte Hamburger's fiktionales Erzählen vs. Aussage ${ }^{28}$. In contrast, some currents of recent French narratology, influenced by the development of enunciative linguistics, have reformulated earlier theories of point of view and focalization ${ }^{29}$, but also of reported speech and techniques of access to character consciousness $^{30}$, and they have done so in ways that significantly revise Benveniste's position by preserving (in revised form) the roles of enunciator and enunciatee.

In its second sense, histoire/discours derives from Tzvetan Todorov's (1966) proposal to replace the Formalist terms with the terms introduced by Benveniste, effectively announcing the "profound unity" between language and narrative that was later put forth as forming the basis of narratology ${ }^{31}$. Narrative as histoire (unlike fabula - a "preliterary material") is a rhetorical inventio, a "convention," an "abstraction" that does "not exist 'in itself," comprising a logic of actions plus characters and their relations and thus forming the langue of narrative. Narrative as discours, a rhetorical dispositio, but also the parole of the individual work, includes the narrative devices of time, aspects (or visions) and modes. The main contribution of these structuralist terms is to have expanded fabula beyond a series of actions to include the continuum of the narrated world ("diegesis," in Genette's terms, as opposed to actions) and sjuzhet beyond the redistribution of events to include all aspects of textual mediation ${ }^{32}$.

All in all, however, it is a misleading choice of words that has led, firstly, to likening histoire and discours, a linguistic theory of the modes of enunciation and communicative situations, with language as system (langue) and language as process (parole) and, secondly, to superimposing these same terms onto, respectively, narrative content and its signifying medium. Todorov himself is equivocal on this point, stating that the "modes of presentation" of narrative ("representation," or characters' speech, and "narration," or narrator's speech) occur "at a more concrete level" than histoire/discours as alternatives to fabula/sjuzhet ${ }^{33}$, which hardly clarifies the English-language story/discourse approach. It is also

28 Banfield's controversial thesis has been systematically reworked within a narratological framework by Monika Fludernik (1993).

29 Rabatel (1997), (1998).

30 Rivara (2000).

31 Todorov (1969: 27).

32 Cf. Martínez/Scheffel (1999: 23).

33 Todorov (1966: 144). 
notable that, in Todorov's version, the features attributed to story and plot are not distributed between histoire and discours, but are necessarily included within the structure of histoire and that, in any case, the author subsequently developed a narrative grammar, replacing histoire with "semantic aspect" (inventio) and "syntactic aspect" (dispositio) and discours with "verbal aspect" (elocutio) (1969), calling, several years later, for a logical analysis in place of a grammatical analysis ${ }^{34}$.

With his narrative grammar, Todorov in fact evolves toward a ternary theory, confirming what has been the undercurrent of the present discussion, namely, that binary models of narrative, when carefully worked out, ultimately subdivide the "what" and/or "how" of narrative in various, even if in sometimes problematical, ways ${ }^{35}$. The story/discourse approach, however, by assimilating fabula/sjuzhet, story/plot, raconté/racontant and histoire/discours into one another, tends to underrate or even to eliminate valuable distinctions in what seems to have left a particular mark on English-language narratology, born largely out of the encounter between point-of-view theories and European structuralism ${ }^{36}$. This is surprisingly true even of approaches to narrative that seek to free themselves of structuralist binarisms, as in the introduction to a recent reader that rejects the "false opposition between 'story' and 'narrative" (sic), adopting an ap-

34 Todorov (1973: 87).

35 Ternary theories are sometimes considered to be fundamentally binary, as Bal (1977: 6) has suggested of Genette. After correctly observing the ambiguity in Genette's narrative (récit), defined both as signifier and enunciate (énoncé-given as "statement" in the English translation of Genette's book), she goes on to point out that narration corresponds to narrative enunciation (énonciation), the enunciate being, in linguistic theory, the result of enunciation, or an act of utterance. Disregarding the latter aspect of narrative (récit), she concludes that Genette only distinguishes between the two levels of Russian Formalism. Even though Genette (1999 [1986]: 330) does maintain that the narratology of fictional texts is linked to comparison of the narrative text with story, he has also reiterated the importance of narration alongside narrative and story (Genette 1988 [1983]: 10ff.), so that the story/discourse dichotomy cannot, in my opinion, be attributed to Genette (cf. Fludernik 1996: 334).

In this regard, it is noteworthy that the first half of Chatman's book is devoted to the events and existents of story and that the second half, with reference to Genette's adoption of Plato's mimésis and diégésis, divides discourse into "nonnarrated stories" (unmediated transmission) and "covert versus overt narrators" (mediated transmission) (cf. 1978: 46), limiting discourse mainly to a discussion of point of view and to what in effect is Todorov's "modes or representation" or Genette's "narrative of events" vs. "narrative of words" and their various permutations. 
parently liberating definition of narrative as "any minimal linguistic (written or verbal) act" ${ }^{\prime 37}$ only to revert, in the glossary, to the very equivalencies that this definition supposedly overcomes: story is "a synonym for histoire or fabula"; discourse is "equivalent" to récit, sjuzhet, plot, muthos ${ }^{38}$.

\section{Semiotic}

Prince's definitions of story and discourse show that these terms cover a variety of concepts, and we have also seen evidence that well-developed theories which incorporate this pair tend, more or less explicitly, to further break it down into constituent categories. In this regard, note can be taken of a lucid encyclopedia entry by Prince, which outlines the principle contributions of classical narratology, discussing narrative grammars from Propp to Barthes' "Introduction" under the heading "Story" and, under "Discourse," Genette. It is noteworthy that, in concluding, the author calls for a more integrated approach with a "narrative grammar proper," consisting in a syntactic component ("a finite number of rules for generat[ing] the macro- and microstructures of all and only stories"), a semantic component interpreting these structures, a "discoursive" component (order of presentation, speed, frequency, etc.) and a pragmatic component ("specifying the basic cognitive and communicative factors affecting the production, processing, and narrativity of the output of the first three parts"), these four parts being articulated with a textual component, i.e. a given medium ${ }^{39}$. This schema resembles Todorov's narrative grammar to the extent that it includes a syntactic component and a semantic component; but unlike the verbal aspect, it provides for a discoursive component (cf. sjuzhet) distinct from a textual component, while it also introduces a pragmatic component which is absent from Todorov's system: interestingly, no explicit reference is made in Prince's narrative grammar to the terms included in the story/discourse model. Does this mean that semiotically-oriented theories of narrative have discarded these terms?

37 McQuillan (2000: 6-7).

38 Ibid.: $317 \mathrm{ff}$.

39 Prince (1995: 125). 
To answer this question, it will be useful to refer to Martínez and Scheffel's comparative table of the basic narratological terms of nineteen theoreticians from Propp to Schmid, classifying them under Handlung (action) and Darstellung (presentation). The first comprises Ereignis (event) (or Motiv), Geschehen (e.g., Forster's "story"), Geschichte ("plot"), and Handlungsschema (abstracted global schema of plots forming groups of texts), while the second is broken down into Erzählung (cf. Tomashevsky's sjuzhet) and Erzählen (presentation of the plot in various languages or media $)^{40}$. Needless to say, this table is not intended to outline a narrative model or theory, but by adopting terms for its classification more general than the terminology employed by any of the theories it includes, the table does allow for a useful overview, making it possible to bring out a number of parallels and differences among these systems as well as inconsistencies and disparities of terminology.

Of particular interest among these systems in the present context is Schmid's four-level model. Noting that the structuralist histoire/discours partially resolves the Formalists' failure to account for the constitution of narrative texts, the author goes on to propose a fabula/histoire and a sjuzhet/discours. The first is subdivided into Geschehen (characters, situations and actions forming "the fictional raw material of narrative processing"a literary inventio) and Geschichte (result of selection, concretization and segmentation - a dispositio in ordo naturalis), while the second is broken down into Erzählung (result of composition through linearization, temporal acceleration/deceleration and permutation of segments - an ordo artificialis) and Präsentation der Erzählung (result of elocutio, verbalization - the pheno-level as opposed to the previous three geno-levels). These levels, arranged vertically, can be viewed from both an "idealgenetic" perspective (the model isolates non-temporal levels of transformation, but corresponds to the creation and reception of no actual work) and a "semiotic" perspective, functioning in the opposite direction and focusing on the constitution of sense or meaning through a series of denotations and implications in the passage from level four to level one $\mathrm{e}^{41}$.

This layout contrasts significantly with Sternberg's system of story, fabula, plot, sjuzhet in that these terms designate "complementary" aspects of narrative, forming the basis of an eight-term typology, and are

${ }^{40}$ Martínez/Scheffel (1999: 25-26).
Schmid (1982: 94-98). 
not ordered into levels either genetically or semiotically. It also bears comparison with Bremond's "interlocking" system which, in effect, subdivides fabula and sjuzhet: not unlike Bremond, Schmid considers Präsentation der Erzählung to be the signifier of Erzählung as signified which, in turn, is the signifier of Geschichte as signified, itself the signifier of Geschehen as signified. In practice, however, Bremond concentrates almost exclusively on isolating the raconté/racontant, whereas Schmid is more concerned with the interactions between fabula/histoire and sjuzhet/discours and their respective subdivisions.

Approaching narrative through four constitutive levels or components opens up a significant perspective for narratology. Referring back to Prince's Dictionary, we see that among the meanings attributed to story is the "content plane" and among those attributed to discourse is the "expression plane," each plane further subdivided into substance and form intersecting in a tabular fashion. Chatman also refers to these two planes, pointing out, however, that his theory is concerned with the form of narrative content and expression (story components plus structure of narrative transmission), rather than with the substance of narrative (representations of objects and actions plus media) ${ }^{42}$, so that, as noted above, he does not in the end adopt Hjelmslev's refinements of Saussure, but remains within a largely Saussurean context. His story/discourse theory thus points in the direction of Hjelmslev's content and expression planes, but does not fully integrate its essential distinctions, while Schmid's four levels, without reference to Hjelmslev, in a sense comes closer to this system, with Geschehen and Präsentation der Erzählung forming the substance, respectively, of content and expression, and Geschichte and Erzählung their form.

I would like now to shift the emphasis somewhat by turning to Umberto Eco's textual semiotics, which incorporates fabula and sjuzhet in a way that reflects content plane/expression plane, doing so, however, within a Peircean framework. Eco's writings in this area are extensive, and for present purposes I will therefore comment only on two interrelated aspects of his textual semiotics: 1) the inferential nature of the sign and the importance of abduction in semiosis; 2) the model of textual communication, which marks a change from the binary to the triadic conception of the sign. The Hjelmslevian perspective, we have seen, serves to

42 Chatman (1978: 24). 
disambiguate the story/discourse model, flawed by the polysemous nature of its terminology, while Eco's approach to abduction and textual communication opens narratology up to the question of semiosis.

Classical narratology, based on the dyadic categories of Saussurean linguistics, adopted a conventionalist notion of the sign: thanks to a code, a correlation is established between content and expression such that " $p$ is equivalent to $q$. ." For Eco, however, the history of semiotics shows that only in a codified form can signs be regarded as identities or equalities, that signs in their dynamic dimension (or, following Hjelmslev, signfunctions ${ }^{43}$ ) result from inference: "if $p$ then $q$." The consequences of this inferential conception of the sign are myriad and far-reaching, including for narratology, for while linguistic theory tends to favor a model of equivalence (" $p$ is $q$ "), a broader understanding of the sign suggests that signs are a matter of interpretation rather than recognition: "A sign," says Eco, "is not only something which stands for something else: it is also something that must be interpreted"44; or as Peirce, quoted in this connection by Eco, puts it: "A sign is something by which we know something more ${ }^{, 45}$; and from a narratological perspective: "story and plot are not functions of language but structures that can nearly always be translated into another semiotic system"46.

Framing the two basic dimensions of narrative in terms of the translatability between semiotic systems rather than in analogy with signified and signifier constitutes an epistemological reorientation of considerable significance for narratology. When narrative is viewed in terms of semiotic functions, for example, it calls for a reexamination of a narrative grammar

43

44

45

46

Cf. Eco (1976: 49), (1988: 119ff.).

Eco (1984: 46).

Peirce (1931 [C.P.]: 8.332, quoted in ibid.: 26).

Eco (1994: 35). Note that although Eco uses Forster's terms interchangeably with the Russian Formalist terms, he remains conceptually closer to the latter: "The fabula is the basic story stuff, the logic of actions or the syntax of characters, the time-oriented course of events"; "The plot [sjuzhet] is the story as actually told, along with all deviations, digressions, flashbacks, and the whole of the verbal devices" (1979: 27). However, as rightly pointed out by Malte Stein in a personal communication, the Formalist fabula is an unordered and formless matter without artistic value, the reader's attention being directed toward the sjuzhet in what is essentially a theory of text production, whereas for Eco, fabula results from a complex process of reconstruction and is thus a structured product of reading and interpretation, sjuzhet being an intermediate step in this process of text reception. 
based on "a profound unity between language and narrative," as advocated by Todorov (1969: 27), while the inferential nature of the sign represents a powerful alternative in narrative studies to the idea that textual manifestation "stands for" narrative content - an alternative explored in detail in The Role of the Reader. In his various writings devoted to inference, Eco adopts the three types of inference that form the basis of Peirce's logic and that are also necessary and sufficient elements for defining the sign: deduction, abduction (or hypothesis), induction. Unlike Peirce, however, who places inferences within a context of scientific verifiability, Eco adapts inferences, calling them abductions, to a theory of cultural representation, where they both serve as a mechanism for interpretation and operate within a textual semiotics ${ }^{47}$.

Overcoded abductions are (semi-) automatic laws resembling deductions to the extent that they proceed with inferences from general laws to particular cases in a mechanical way. They also involve hypotheses in that, for instance, to know whether the graphemes 't,' 'a,' 'b,' 'l,' 'e' are pronounced /teibl/ or /tabl/, I must decide, possibly on the basis of circumstantial evidence, whether these graphemes pertain to the English language or to the French language: in such examples, overcoding frequently occurs, since context of utterance and cotext render the decision nearly automatic. In literary texts, overcoding results from genre, style, and rhetoric, but can also be found in the structure of narrative functions identified by Propp, in actantial structures and in frames. Here, type and token come into play so that, according to Eco, "[a] story actualizes preovercoded narrative functions, that is, intertextual frames"48.

Undercoded abductions (or abductions stricto sensu) come into play in the absence of reliable predictable rules, and they involve the selection of the most plausible alternative that can be entertained, moving from an inference to a probable rule. This is the case when a series of disconnected data are joined together to form a coherent sequence, or when the identification of a topic brings out the "aboutness" of a text. "Is Oedipus Rex," asks Eco, "the story of detection, incest, or parricide?"49. To answer such

47 The following comments are based mainly on Eco (1976: 129-36), (1979: 17ff.), (1984: 39-43), (1988: 48-53), (1990: 64-82, 152-60), (1994: 156-60); see also Thagard (1978); Bonfantini/Proni (1983); Schillemans (1992); Ayim (1994); Manetti (2000).

48 Eco (1979: 35).

49 Eco (1979: 28). 
a question, it is necessary to take an "inferential walk" outside the text in search of previously actualized frames, an operation likened to passing from a definition contained in the dictionary to the text-oriented world knowledge embraced by the encyclopedia. Verisimilitude is another product of undercoded abductions, as when we infer from Forster's ministory "The king died and then the queen died" that the queen died of grief. In contradistinction with the notion of textual immanence, it is the back-and-forth movement between overcoded and undercoded abductions, between the "ready-made" and the merely plausible, that allows for construction of the fabula.

Creative abductions, like undercoded abductions, resemble abduction in Peirce, but they involve the invention of new rules and thus operate as a conjecture or a bet against the odds when no plausible inference is available. Creative abductions may challenge existing scientific and ideological paradigms, and they also enter into the process by which a detective uncovers the facts. Unlike overcoded and undercoded abductions, however, which rely on preexisting and pretested explanations, creative abductions are closely linked with Peirce's induction - the testing of hypotheses - or what Eco calls "meta-abduction": to what degree do new inductions coincide with world knowledge and experience? To answer such a question, the encyclopedia is resorted to through a process of metaabductive reasoning, and it is employed when, for instance, possible worlds are confronted with the "real" world.

It is frequently recognized that one of the meaningful aspects of Eco's textual semiotics is that it is marked by the transition from a dyadic to a triadic conception of the sign. This is due in part to the syllogistic nature of Peirce's inferential logic which, at the level of the sign, results in the incorporation of the interpretan $t^{50}$ into semiosic processes, the interpretant being, for Eco, the cornerstone of interpretation and of the Model Reader. The centrality of interpretation in Eco's semiotics is reflected in his model of textual communication, as developed particularly in The Role of the Reader and summarized in figure 1 .

50 "A sign addresses somebody, that is, creates in the mind of that person an equivalent sign, or perhaps a more developed sign. That sign which it creates I call the interpretant of the first sign" Peirce (1931 [C.P.]: 2.228). 


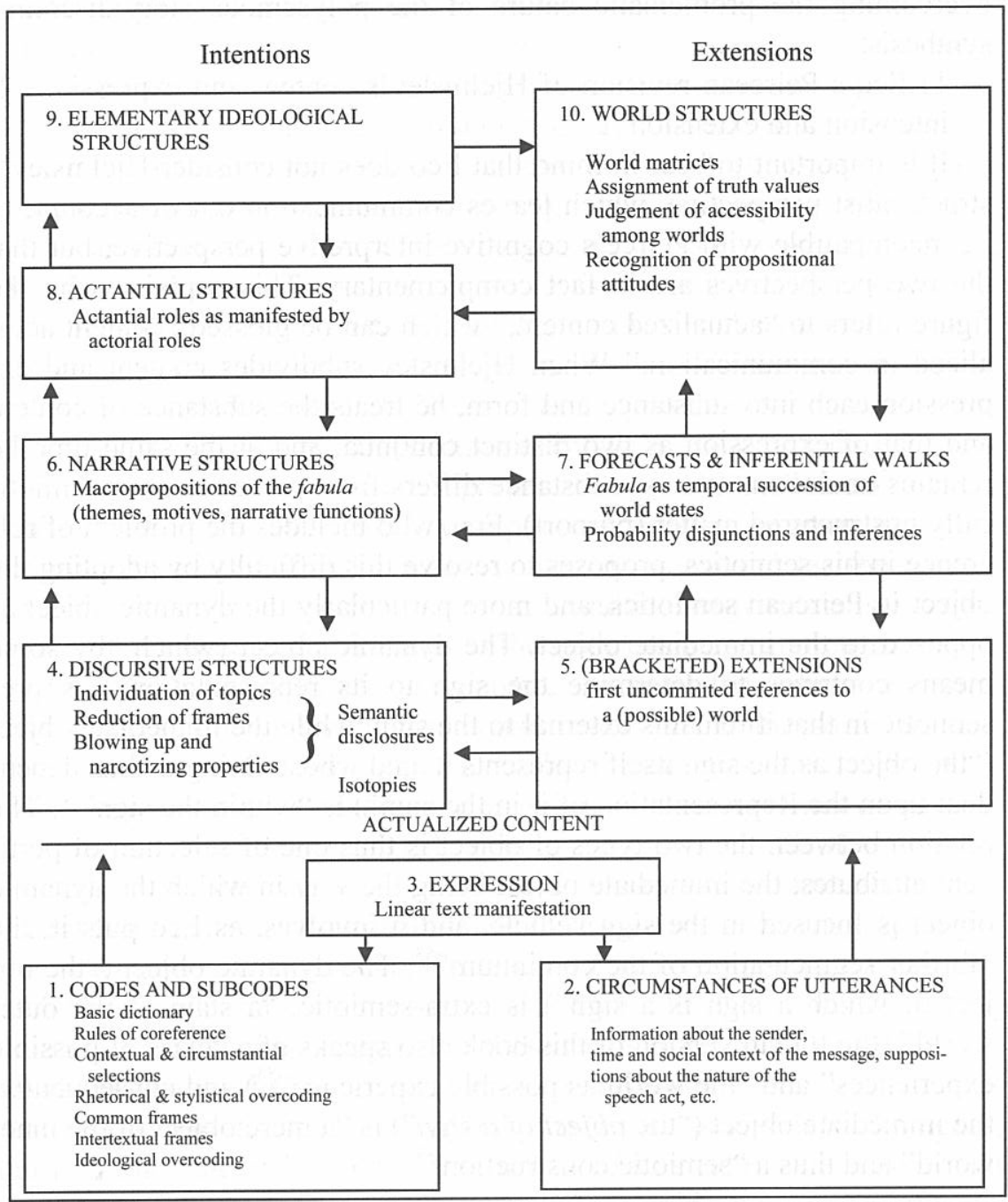

Figure 1: Eco's model of textual communication.

Source: Eco (1979: 14).

I do not propose to give a detailed commentary on this figure or to compare it with Jakobson's well-known model of verbal communication (which would require a separate study), but only to draw attention to two of its features that have extensive consequences for the conceptual status of narrative categories in general and that offer considerable potential for 
overcoming the problematic nature of the polysemous story/discourse synthesis:

1) Eco's Peircean revision of Hjelmslev's content and expression; 2) intension and extension ${ }^{51}$.

It is important to bear in mind that Eco does not consider Hjelmslev's structuralist perspective, which leaves communication out of account, to be incompatible with Peirce's cognitive-interpretive perspective, but that the two perspectives are in fact complementary. This explains why the figure refers to "actualized content," which can be glossed "content actualized in communication." When Hjelmslev subdivides content and expression each into substance and form, he treats the substance of content and that of expression as two distinct continua, and at the same time he remains unclear as to how substance differs from presemiotic or semiotically unstructured matter (purport). Eco, who includes the problem of reference in his semiotics, proposes to resolve this difficulty by adopting the object in Peircean semiotics, and more particularly the dynamic object as opposed to the immediate object. The dynamic object (which "by some means contrives to determine the sign to its representation") is presemiotic in that it remains external to the sign, while the immediate object ("the object as the sign itself represents it, and whose Being is thus dependent upon the Representation of it in the sign") is "within the sign"52. The relation between the two types of object is thus one of selection of pertinent attributes, the immediate object being the way in which the dynamic object is focused in the sign-vehicle, and it involves, as Eco puts it, the "further segmentation of the continuum"s3. The dynamic object ("the object of which a sign is a sign") is extra-semiotic, "a state of the outer world" (the Italian version of this book also speaks of a "class of possible experiences" and "the world as possible experience" ${ }^{\text {"54 }}$ ) and consequently, the immediate object ("the object of a sign") is "a mere object of the inner world" and thus a "semiotic construction",55.

51 The following remarks are made mostly in reference to Eco (1976: 48-58, 268-70), (1979: 3-43), (1984: 33-36, 44ff.), (1988: 119-35); see also Dolezel (1997); Caesar (1999: 83-86, 120-34); Violi (2000).

52 Peirce (1931 [C.P.]: 4.536); quoted in Eco (1979: 181).

53 Eco (1976: 269).

${ }_{55}^{54}$ Cf. Violi (2000: 31).

55 Eco (1979: 193). 
It is fairly obvious from the figure that actualized content coincides with the immediate object. The dynamic object (Hjelmslev's continuum or matter) is not represented here and in fact cannot be and need not be, since it is knowable only through the articulations of textual signfunctions. As for expression, it can employ various portions of the continuum, segmenting it in different ways (e.g., the visual representation of an object as opposed to a verbal description of the same object). Referring back to the story/discourse model, we can see that it includes no distinction comparable to that between dynamic object and immediate object: Chatman's evocation of the substance and form of content and of expression remains indeterminate with regard to the presemiotic continuum, and it ultimately comes down to equating events and existents with the signified and the medium with the signifier that "stands for" them ${ }^{56}$. Eco's model, based on an inferential conception of the sign, is oriented toward the abductive operations by which content is actualized (as the various boxes in the figure attempt to chart out), and it thus stands in stark contrast with the dyadic equivalences of the story/discourse approach.

Not only does the model incorporate the immediate object into content, but it also includes intensions and extensions, doing so in place of denotation and connotation in Hjelmslev's semiotics. In A Theory of Semiotics, Eco studied denotation and connotation in terms of cultural codes (e.g., an electronic signal "denotes" a certain level of water in a dam and "connotes" danger). Later, however, he became more attached to the relations between signification and truth conditions or, roughly speaking, intension and extension, the terms frequently used in conjunction with the logical and semantic theories of Frege, Russell, Carnap, etc., although Eco's immediate source for these terms is Petöfi's Text-StructureWorld-Structure-Theory. It may be an oversimplification to state that structuralist narratologies concern only the "intensions" side of the figure, but it is true that such theories tend not to venture into "extensions," and the interest of Eco's figure is to provide in graphic form a semiotic account of referentiality in narrative communication which includes an encyclopedia model of semantics with a strong pragmatic element. Here again, abductive processes are the key to the relations between the various

56 It must also be objected that, in semiotic theory, the signifier does not "stand for" the signified; it is, rather, the sign that stands for something to somebody in some respect or capacity, as Peirce would have it. 
boxes (which Eco is careful not to confuse with the "levels" of many narrative theories), with overcoded abductions being prominent vertically and undercoded, creative, and meta-abductions tending to come into play horizontally. A look at the intensions side, for example, suggests that discursive structures (4) are overcoded by codes and subcodes (1) and by narrative structures (6). Plot, which coincides more or less with discursive structures (4), results from a tentative synthesis by the reader, thus involving undercoded abductions or, in "open" texts, creative abductions, while the movement toward bracketed extensions (5) engages a process of metaabductions, the "testing" of hypotheses. A similar process takes place at the more abstract level of narrative structures (6) and forecasts and inferential walks (7) with the mapping of macropropositions onto world states.

Expression, or linear text manifestation, is dependent on codes and subcodes (i.e. presupposed knowledge), which are included among intensions, and it is also subject to circumstances of utterance (or pragmatic conditions), included among extensions. For Eco, then, expression is linked to pragmatic categories, rather than to the division into substance and form, and it therefore functions in conjunction with the semantic intensions and extensions of actualized content.

The replacement of the substance and form of expression and content by pragmatic and semantic categories reflects the intersection of the Hjelmslevian and the Peircean perspectives in the model of textual communication, and it also results from an attempt to reconcile two fundamental orientations in sign theory, namely, signification (corresponding roughly to binary theories of the sign) and communication (triadic theories). Furthermore, as can be seen from the figure, the four major components of textual communication are not arranged into the "vertical" levels of some theories (cf. Schmid) or into the tabular form presupposed by Chatman's appropriation of content and expression and their subdivisions. Nor do these components follow the "horizontal" arrangement of the sender-receiver models, inspired by theories of information, that have been adopted by numerous narratologists. Such a model is taken over by Chatman (1978: 267) in his diagram of narrative structure, which includes real author/reader, implied author/reader and mediated transmission (narrator to narratee) as opposed to unmediated transmission ("no" or minimal narrator); at the same time, however, this diagram reveals a shift away from the tabular configuration of Hjelmslev's expression and content and their subdivisions. By contrast, neither Schmid's nor Eco's systems incorporate sender-receiver theories of communication. Schmid's four-level 
system, we have seen, has both an "ideal-genetic" or transformational dimension and a "semiotic" dimension of sense and meaning, and it is also oriented toward the production of narrative texts. Eco's textual communication, due to its connection with inferential reasoning and the triadic conception of the sign in Peircean semiotics and the importance of the interpretant, accentuates textually regulated interpretive acts carried out by the recipient, or the Model Reader, but it does not address such traditional concerns of narratology as time, focalization, representation of character/narrator discourse or reliable/unreliable narration.

The terms story and discourse form part of the landscape of discussions about narrative and to reject them, whatever the difficulties brought about by their use, would be as pointless as to propose fresh new definitions of them. What is more important, as I have attempted to show here, is to identify, not only how story and discourse have been associated with similar terms and concepts, but also the ways they are appropriated by and operate within various narrative theories. At the least, this can perhaps help to avoid some of the pitfalls of facile and ready-made syntheses inherited from several decades of narratological studies. At best, this inquiry into the two major dimensions of narrative, together with their semiotic parameters, can serve to enlarge the horizons of narrative research. 


\section{References}

Ayim, Maryann

1994 "Abduction," in Encylopedic Dictionary of Semiotics, 2nd edition, revised and updated (1st edition 1986), Approaches to Semiotics, edited by Thomas A. Sebeok et al., 1-2 (Berlin and New York: Mouton de Gruyter).

Bal, Mieke

1977 Narratologie. Les instances du récit (Paris: Klincksieck).

1997 Narratology. Introduction to the Theory of Narrative, 2nd edition (1st edition Banfield, Ann 1985) (Toronto, Buffalo, London: University of Toronto).

1982 Unspeakable Sentences: Narration and Representation in the Language of Fiction (Boston: Routledge \& Kegan Paul).

Benveniste, Emile

1966 [1959] "Les relations de temps dans le verbe français," in E.B. Problèmes de linguistique générale, 237-57 (Paris: Gallimard).

Bonfantini, Massimo A. / Proni, Giampaolo

1983 "To Guess or not to Guess?," in The Sign of Three: Dupin, Holmes, Peirce edited by Umberto Eco and Thomas A. Sebeok, 119-34 (Bloomington and Indianapolis: Indiana UP).

Bremond, Claude

1966 "La logique des possibles narratifs," in Communications 8: 60-76.

1973 [1964] "Le message narratif," in C.B. Logique du récit, Collection Poétique, 11-47 (Paris: Editions du Seuil).

Caesar, Michael

1999 Umberto Eco. Philosophy, Semiotics and the Work of Fiction (Cambridge (UK): Polity Press).

Capozzi, Rocco (ed.)

1997 Reading Eco: An Anthology (Bloomington and Indianapolis: Indiana UP).

Chatman, Seymour

1978 Story and Discourse. Narrative Structure in Fiction and Film (Ithaca and London: Cornell UP).

Dolezel, Lubomír

1972 "From Motifemes to Motifs," in Poetics 4: 55-90.

1997. "The Themata of Eco's Semiotics of Literature," in Reading Eco: An Anthology, edited by Rocco Capozzi, 111-20 (Bloomington and Indianapolis: Indiana UP).

1998 Heterocosmica: Fiction and Possible Worlds (Baltimore: Johns Hopkins UP).

Eco, Umberto

1976 A Theory of Semiotics (Bloomington: Indiana UP).

1979 The Role of the Reader: Explorations in the Semiotics of Texts (Bloomington: Indiana UP).

1983 "Horns, Hooves, Insteps: Some Hypotheses on Three Types of Abduction," in The Sign of Three: Dupin, Holmes, Peirce, edited by Umberto Eco and Thomas A. Sebeok, 198-220 (Bloomington, Indianapolis: Indiana UP). 
1984 Semiotics and the Philosophy of Language (Bloomington: Indiana UP).

1988 Le signe. Histoire et analyse d'un concept, adapted from the Italian by JeanMarie Klinkenberg (Brussels: Editions Labor).

1990 The Limits of Interpretation (Bloomington and Indianapolis: Indiana UP).

1994 Six Walks in the Fictional Woods (Cambridge (US) and London: Harvard UP).

Eco, Umberto / Sebeok, Thomas A. (eds.)

1983 The Sign of Three: Dupin, Holmes, Peirce (Bloomington and Indianapolis: Indiana UP).

Erlich, Victor

1969 Russian Formalism: History - Doctrine, 2nd revised edition (1st edition 1955) (The Hague and Paris: Mouton).

Fludernik, Monika

1993 The Fictions of Language and the Languages of Fiction. The Linguistic Representation of Speech and Consciousness (London and New York: Routledge).

1996 Towards a "Natural" Narratology (London and New York: Routledge).

Forster, E. M.

1962 [1927] Aspects of the Novel (Harmondsworth: Penguin).

Genette, Gérard

1980 [1972] Narrative Discourse: An Essay in Method, trans. by Jane E. Lewin (Ithaca: Cornell UP).

1988 [1983] Narrative Discourse Revisited, trans. by Jane E. Lewin (Ithaca: Cornell UP).

1999 [1986] "Une logique de la literature," in G.G., Figures IV, Collection Poétique, 323-33 (Paris: Editions du Seuil).

Herman, David

1995 Universal Grammar and Narrative Form (Durham and London: Duke UP).

1999 "Introduction: Narratologies," in Narratologies: New Perspectives on Narrative Analysis, edited by David Herman, 1-30 (Columbus: Ohio State UP).

Lemon, Lee T. / Reis, Marion J. (eds.)

1965 Russian Formalist Criticism: Four Essays, trans. and ed. by Lee T. Lemon and Marion J. Reis, 61-95 (Lincoln: University of Nebraska).

Manetti, Giovanni

2000 "Inférence et équivalence dans la théorie du signe d'Umberto Eco," in Au nom du sens: autour de l'œuvre d'Umberto Eco, edited by Jean Petitot and Paolo Fabbri, 157-72 (Paris: Bernard Grasset).

Martínez, Matías / Michael Scheffel

1999 Einführung in die Erzähltheorie (Munich: C.H. Beck).

McQuillan, Martin (ed.)

2000 The Narrative Reader (London and New York: Routledge).

Peirce, Charles Sanders

1931 [1931-1958] Collected Papers, Vols. 1-6 edited by Charles Hartshorne and Paul Weiss; vols. 7-8 edited by Arthur W. Burks (Cambridge (US): Harvard UP).

Petitot, Jean / Fabbri, Paolo (eds.)

2000 Au nom du sens: autour de l'œuvre d'Umberto Eco (Paris: Bernard Grasset). 
Prince, Gerald

1987 A Dictionary of Narratology (Lincoln and London: University of Nebraska).

1995 "Narratology," in From Formalism to Poststructuralism, Vol. 8 of The Cambridge History of Literary Criticism, edited by Raman Selden, 110-30 (Cambridge (UK): Cambridge UP).

Rabatel, Alain

1997 Une histoire du point de vue, Recherches textuelles 2 (Metz: Université de Metz).

1998 La construction textuelle du point de vue. Sciences du discours (Lausanne: Delechaux et Niestlé).

Rimmon-Kenan, Shlomith

1983 Narrative Fiction: Contemporary Poetics (London: Methuen).

Rivara, René

2000 La langue du récit: Introduction à la narratologie énonciative, Collection "Sémantiques" (Paris: L'Harmattan).

Schillemans, Sandra

1992 "Umberto Eco and William of Baskerville: Partners in Abduction," in Semiotica 92.3-4: 259-85.

Schmid, Wolf

1982 'Die narrativen Ebenen 'Geschehen,' 'Geschichte,' 'Erzählung' und 'Präsentation der Erzählung, ”’ in Wiener Slawistischer Almanach 9: 83-110.

Scholes, Robert

1980 "Language, Narrative, and Anti-Narrative," in Critical Inquiry 7.1: 204-12.

Sebeok, Thomas A. et al. (eds.)

1994 Encylopedic Dictionary of Semiotics, 2nd edition, revised and updated (1st edition 1986), Approaches to Semiotics 73 (Berlin and New York: Mouton de Gruyter).

Selden, Raman (ed.)

1995 From Formalism to Poststructuralism, Vol. 8 of The Cambridge History of Literary Criticism. Cambridge (UK): Cambridge UP.

Sternberg, Meir

1978 Expositional Modes and Temporal Ordering in Fiction (Bloomington and Indianapolis: Indiana UP).

Thagard, Paul R.

1978 "Semiosis and Hypothetic Inference in Ch. S. Peirce," in Versus 19-20: 163-72.

Todorov, Tzvetan

1966 "Les catégories du récit littéraire," in Communications 8: 125-51.

1969 Grammaire du Décaméron (The Hague and Paris: Mouton).

1973 Poétique, Collection Points (Paris: Editions du Seuil).

Tomashevsky, Boris

1965 [1925] "Thematics," in Russian Formalist Criticism: Four Essays, trans. and ed. by Lee T. Lemon and Marion J. Reis, 61-95 (Lincoln: University of Nebraska).

Toolan, Michael

2001 Narrative: A Critical Linguistic Introduction, 2nd edition (1st edition 1988) (London and New York: Routledge). 
Violi, Patrizia

2000 "Eco et son référent," in Au nom du sens: autour de l'œuvre d'Umberto Eco, edited by Jean Petitot and Paolo Fabbri, 21-40 (Paris: Bernard Grasset).

Volek, Emil

1977 'Die Begriffe 'Fabel' und 'Sujet' in der modernen Literaturwissenschaft. Zur Struktur der "Erzählstruktur,"” in Poetica 9: 141-66.

Weinrich, Harald

1971 Tempus. Besprochene und erzählte Welt, 2nd revised edition (1st edition 1964) (Stuttgart: Verlag W. Kohlhammer). 